\title{
Comparative Study on the Use of Legal Instruments in Asean Economic Community
}

\author{
Evi Retnowulan \\ Law Faculty \\ Universitas Narotama \\ Surabaya, Indonesia \\ evi.retno@narotama.ac.id
}

\author{
Anang Setiyawan \\ Law Faculty \\ Universitas Wiraraja \\ Sumenep, Indonesia \\ anang.setiyawan.sh@gmail.com
}

\begin{abstract}
By the end of 2015 Asean countries have entered the era of Asean Economic Community (AEC). AEC aims to create a competitive and integrated economic region with the global economy through an integrated economic region in the form of a single market and a common industry base. AEC is form of globalization that provides public welfare and the same time inviting decline (Held), erosion (Hall), and the end of the nation of state (Ohmae). Law has fundamental role to accelerate development progress, enhance competitiveness, and protect national interests while reducing the negative impacts arising from the enactment of the AEC. Law is a means to embody the policy and provide legitimacy for the implementation of government policy in order to organize the community and direct the community in accordance with the purposed goals. Small and Medium-sized Enterprises is one of economic backbone for Asean countries. This study would like to see how countries in Asia formulate policies and regulations to develop at once this potential sector. The results of the study can be an input to policy makers by both local and central government in using the law as an instrument to accelerate their economic progress
\end{abstract}

Keywords-Asean Economic Community, Law, Public Policy, Comparative Law, National Interest.

\section{INTRODUCTION}

Late 2015 Asean countries entered the era of Asean Economic Community (MEA). MEA aims to create a competitive and integrated economic region with the global economy through an integrated economic region in the form of a single market and a common industry base. MEA encourages Asean countries to compete in preparing human resources, improving product quality and reforming their country's regulations and policies. Behind it, the MEA is one form of globalization that provides an opportunity to be used as a tool for the welfare of society, but also invites decline (Held), erosion (Hall), and the end of nation of state (Ohmae), even referred to as "the el nino of the social sciences ", a force that is considered to be blamed for all the damage in society ${ }^{1}$.[1] it is necessary law as an instrument of government policy so that law order, legal certainty and legal utility can still be achieved.

Law has fundamental role to accelerate development progress, increase competitiveness, and protect national interests while reducing the negative impacts arising from the implementation of the MEA. Law is a means of realizing policies and providing legitimacy for the implementation of government policy in order to achieve the desired objectives. Law is used as a means of public policy because the law has several advantages, namely rational, integrative, legitimate, supported by the implementation mechanism and sanctions.

One of sectors that become the economic backbone in the Asean Countries is the small and medium-sized enterprises. This study would like to see how countries in Asia formulate policies and regulations to develop at once this potential sector. The results of the study can be an input to policy makers by both local and central government to learn from other Asean countries in using the law as an instrument to accelerate their economic progress.

\section{SMALl Medium ENTERPRISE (SME) POLICY IN ASEAN}

Small Medium Enterprises (SME) is the main engine and backbone of the economy in Asean countries. The importance of Small Medium Enterprises to the health of the economy has long been recognized by Asean countries. This is because the SME field plays an important role in supporting economic growth in both the developed and long-term developing countries through increased employment opportunities, increasing innovation, increasing GDP and foreign exchange through export, enhancing regional 
development equity, strengthening the competitiveness and economic resilience of the Asean region.[2]

Significance of Small Medium Enterprises is seen from the large number of companies in the Asian region where 89-99 percent of them are SME, absorb up to 98 percent of employment, contributing up to 58 percent of GDP and contributing up to 30 percent of total exports.[3]

The importance of SME development in the Asian region led Asian leaders in 2004 to formulate a special SME policy of "ASEAN Policy Blueprint for SME Development 2004-2014" aimed to facilitate the emergence of a SME sector which is characteristically entrepreneurial, growth oriented, outward-looking, modern and innovative. In 2009, Asean Economic Minister (AEM) developed "ASEAN Strategic Action Plan for SME Development 2010-2015" to accelerate the implementation of the blueprint. This strategic plan is designed to include efforts on access to finance, technology development, human resources to enhance the resilience and competitiveness of SME.[4]

The importance of SME development is then reflected again in the Asean Economic Community blueprint 20162025. The ASEAN Strategic Action Plan for SME Development (SAPSMED 2016-2025) has a vision for creating globally competitive, resilient and innovative MSMEs integrated into the ASEAN community and participating in inclusive development in the Asean region. In this strategic plan outlined 5 strategic objectives, as follows:[5]

Promote productivity, technology, and innovation Increase access to finance Enhance market access and "internationalization"; Enhance policy and regulatory environment; Promote entrepreneurship and human capital development

\section{A. Singapore}

At the 25th Asean Summit of 2014, the Prime Minister of Singapore declared that an economically, stronger, and more unified Asean could attract investment, create jobs, manage regional challenges and be an effective platform against larger forces. This statement is essentially true given that individual countries are still too small to take full advantage of global opportunities while preventing uncertainties and shocks arising from both inside and outside the region ${ }^{6}$.

Asean is currently experiencing strong growth and became one of the third largest economic growth engines after China and India with GDP of US \$ 2.4 trillion and annual growth is projected an average of 5.4\% from 2014 to 2018. The Organization for Economic Co- operation and Development (OECD) expects GDP growth for Asean communities to be $5.2 \%$ annually from 2016 to 2020 . This is supported by several favorable factors such as increased foreign direct investment, large human and natural resources. This can turn Southeast Asia into the center of consumerism and manufacturing in the world ${ }^{7}$.

Chief executive of HSBC Singapore stated that if the Asean Economic Community is well implemented it will increase Singapore's GDP to 9.5 percent higher by 2030 than if the country is not part of the Asean Economic Community ${ }^{8}$. The Small and Medium-sized Enterprises for 20 years continue to play an important role in the Singapore economy as an important pillar of the economy. During 1997 to 2015 the number of SMEs in Singapore was doubled and had workers tripled than before. In 1997 Singapore SMEs totaled 98,000 and by 2015 doubled by 188,000 , while workers absorbed by this field in 1997 amounted to 800,000 and by 2015 nearly tripled by 2.2 million workers.

The Small and Medium-sized Enterprises Committee (SMEC) states that future economic growth will be further fueled by technological innovation and transformation which, therefore, Singapore must develop new growth engines fueled by technology, innovation and entrepreneurial talent. At the 2017 budget, SMEC urges the Singapore government to consider the importance of creating a third growth engine and continue to provide broad support for The Small and Medium-sized Enterprises. Creating this third growth machine is very important because high-growth, promising local companies can start to grow and develop into competitive and singapore companies can continue to be an attractive place for talented entrepreneurs and companies with technology and innovation. As stated by the Chairman of SMEC that ${ }^{9}$; 
"To achieve this, we have to transform into a creative entrepreneurial nation that can attract foreign entrepreneurial talents and high technology enterprises to settle here, form joint ventures with local enterprises and create new businesses that will help propel our economy"

The third growth strategy according to SMEC can be achieved through six recommendations, as follows ${ }^{10}$;

Economic key performance indicators (KPIs) of developing high growth companies.

Private bourse for innovative

companies. Asset protection for

business continuity Talent attraction

\section{Intellectual property financing}

Based on the significance of SME's contribution to GDP growth, Singapore has provided a special boost to SMEs in addressing financial and resource issues, including Capability Development Grant that helps SMEs start from adopting technology to expanding overseas business. The ACE Startups program, one of its programs, provides mentors to SMEs to support their first year startup efforts. Spring Startup Enterprise Development Scheme utilizing SPRING SEEDS Capital, SPRING's investment arm to grow SME with investment. Interactive Digital Media (IDM) 's IDM Jumpstart and Mentor program targets registered individuals and registered companies. IE Singapore's Global Company Partnership (GCP) benefits SME's business to global competitiveness. The International Expansion Grant (Market Readiness Assistance Grant) aimed at accelerating the expansion of local SMEs internationally $^{11}$.

\section{B. Malaysia}

Asean Economic Community is an important part of a larger political-economic objective to create a common market in all Asean countries that allows free flow of goods, services and investment to create a dynamic and competitive economy. Malaysia's participation in the AEC provides opportunities for Malaysian companies to have greater market access than domestic markets and new opportunities for small and medium businesses ${ }^{12}$.

Through the Asean Economic Community, Malaysia can improve domestic competitiveness because of the large number of goods and services traded between countries at much cheaper prices. The lower price of goods and services makes the Malaysian government have more funds to spend on other sectors. The country has also been able to reduce the selling price of palm oil that is able to attract the demand of other countries that ultimately contribute to the Malaysian economy. By opening up to international trade it is deemed able to encourage other States to work more closely together to create a production method whereby each State has specialized specialist areas to gain maximum benefit from international trade.

As in other Asian countries, Small and Medium Enterprise (SME) also plays a vital role in the Malaysian economy as the backbone of the country's domestic industry development. SME's contribution to GDP continues to increase, from 29 per cent in 2005 to 32.3 per cent in 2011 and to 36.6 per cent by 2015 , this sector is forecast to continue to increase materials will reach 41 per cent against GDP by $2020^{13}$. According to the SME 2016 census report there are 907,065 SMEs running their business in Malaysia. 89.2\% of SME is engaged in the service sector, $5.3 \%$ is engaged in the manufacturing sector, $4.3 \%$ is in the construction sector, $1.1 \%$ is engaged in agriculture and $0.1 \%$ of them are engaged in the mining and quarrying sector $^{14}$

Malaysia has the National SME Development Council (NSDC) which is the highest policy-making body that encourages a holistic and coordinated approach to SME development. Since its establishment in 2004, it has encouraged the development of SMEs in Malaysia by providing strategic direction and formulating policies that act as a growth catalyst in all sectors of the economy. The success of this institution can be seen from the contribution of SME 29.6 per cent in 2005 increased to 36.6 per cent by 2016. In addition, the agency has succeeded in defining the SME definition standard, developing SME databases, monitoring and analyzing SME performance, developing SME financial infrastructure and compiling SME Master plan 2012-2020.

Policy on The Tenth Malaysia Plan (10 MP) 2011-2015 establishes a stage of structural transformation to drive Malaysia towards a high-income country. One of the main points of this plan is to empower SME and entrepreneurship as an engine of growth and innovation that ultimately encourages the formulation of SME master plan. This Master plan places strategies, actions and programs to create an enabling environment for SME development as a new growth engine with a focus on ease of doing business, access to finance and markets, human resources, entrepreneurship development and SME innovation. The Eleventh Malaysia Plan (11 Mp) 20162020 highlights four key areas of productivity, innovation, entrepreneurship and inclusiveness aimed at promoting SME growth, sustainability and sustainability so that SMEs can empower SMEs in the face of future economic challenges. SME master plan serves as a sectoral development base to bring SME to the next 
development level to increase SME's contribution to GDP to 41 percent by 2020 .

The agency responsible for coordinating and encouraging the master plan is SME Corp. Malaysia that serves as the Central Coordinating Agency (CCA). SME Corp. Malaysia coordinates and encourages a masterplan focusing on the implementation of six High Impact Programs (HIPs), which are:

HIP 1: Integration of Business Registration and Licensing. The program aims to provide ease in doing business by creating a single place through the National Business Registration System (MyCoID) and the National Business Licensing System (BLESS).

HIP 2: Technology Commercialization Platform. The project was implemented by the Malaysian Innovation Agency to build a privately run network platform to promote innovative ideas as a commercialization concept stage.

HIP 3: SME Investment Partner. This program provides early stage financing through the establishment of an investment company to invest in potential SMEs in the form of forest, equity and / or combined both.

HIP 4: Going Export Program. The program is managed by Malaysia External Trade Development Corporation (MATRADE) by offering special support assistance to new exporters and SMEs to expand into new markets with the aim of internationalizing SMEs that are ready for export.

HIP 5:d Catalyst Program. The program creates champions in their own country through a planned approach with financial support, market access and human resource development.

HIP 6: Inclusive Innovation. The program aims to help those in the income group under $40 \%$ to leverage innovation through transformation through a handholding approach. The project is implemented by the Ministry of Science, Technology and Innovation (MOSTI) through the Malaysian Innovation Foundation (YIM).

In 2006 the government issued the Companies Act 2016 and set up productivity blueprint that is expected to have a positive impact on SME development and entrepreneurship in Malaysia. Companies act 2016 to ensure that Malaysian law is in line with the development of the global business community and aims to facilitate business preparation and operations through a new legal framework, simplifying laws and procedures and removing barriers to boost SME growth in Malaysia.

Companies act 2016 to ensure that Malaysian law is in line with the development of the global business community and aims to facilitate business preparation and operations through a new legal framework, simplifying laws and procedures and removing barriers to boost SME growth in
Malaysia.

This law complies with global standards to ensure the road to business start in Malaysia is much easier, cost-effective and flexible to enhance competitiveness that will eventually attract more investment and boost SME growth. by 2017 blueprints are launched to increase productivity levels at national, sectoral and enterprise levels through appropriate initiatives to address productivity challenges in the SME sector. The target is to increase the productivity of workers from 1.8 percent annually in the period of $10 \mathrm{MP}$ to 3.7 percent annually in the period of $11 \mathrm{MP}$. This Blueprint contains five strategic goals that will form the basis of recommendations to improve productivity. The five strategic objectives are then spelled out into several national-level initiatives that need immediate action, as follows ${ }^{15}$;

Building Workforce of the Future. To accomplish this goal it is necessary to first, make structural changes to the workforce by formulating labor market policies including reducing dependence on workers with low wages and skills. Second, implement national strategic manpower planning to anticipate changes in labor needs across sectors.

Driving Digitalization and Innovation. This goal is achieved by reinforcing the readiness, knowledge and use of technology by cross-sectoral companies and strengthening the digitalization between SMEs through e-commerce and the use of innovative technologies.

Making Industry Accountable for Productivity. This goal is achieved by gradually reducing dependence on unnecessary subsidies and ensuring liberalization efforts related to productivity outcomes. Then, readjust the grants, incentives, soft loans and funding mechanisms.

Forging a Robust Ecosystem. This target is achieved by first, accelerating efforts to improve the government's overall approach to overcoming regulatory barriers. Second, establishing accountability mechanisms for the implementation of regulatory review by the government.

Securing a Strong Implementation Mechanism. This objective is achieved by first, instituting coordination and governance models to ensure implementation assurance at government, sectoral and enterprise level. Second, launch a national productivity movement to instill a stronger productivity culture in society.

\section{Indonesia}

Indonesia as the largest country in ASEAN both geographically and demographically should work hard in 
preparing itself to face ASEAN economic community. but the Government of Indonesia is still slow in preparing legal instruments to deal with MEA. Delays in formulating policies on ASEAN have a direct impact, for example in East Java, East Java's intertemporal analysis in the ASEAN region can be noted that in 2007-2013, East Java lost 122 leading commodities, causing East Java exports to decline from USD 835 million to USD 73 Million ${ }^{16}$.

In 2008, Indonesia initiated its steps in formulating legal instruments in preparing to face the MEA by issuing Presidential Directive No. 5 year 2008 on the Focus of the 2008-2009 Economic Programs. The directive contains all government policies aimed at promoting national economic growth, sustainability of natural resources, enhancing energy security and environmental quality, and for the implementation of various commitments of the Association of Southeast Asian Nations (ASEAN) Economic Community. These measures are guided by programs covering improved investment climate, macroeconomics and finance, energy security, natural resources, environment and agriculture, empowerment of micro, small and medium enterprises, implementation of ASEAN Economic Community commitments, infrastructure, employment and transmigration. The implication of the Presidential Decree is ineffective in preparing the implementation of the ASEAN Economic Community, as evidenced by the absence of a heavily regulated and massive policy, even the legal instruments that implement the ASEAN Economic Community commitments are not found.

In 2011, the President issued the Presidential Directive Number 11 Year 2011 on the Implementation of the Commitment of the Association of Southeast Asian Nations Economic Blueprint of 2011. This directive is considered more concrete than Presidential Directive No. 5 year 2008 because it has set in more detail what the government should do in the face of the ASEAN Economic Community, although the evaluation of performance achievements on such instructions has never been published. This directive contains the program guidelines for the Implementation of the Commitment of the Association of Southeast Asian Nations Economic Community Blueprint, which are:

Towards a single market and production base, which focuses on Increased competitiveness and utilization of AEC commitment; AEC's commitment to free goods flow; AEC's commitment to free flow of services; AEC commitment to free investment flow; AEC's commitment to more free capital flows; priority integration sectors; and AEC commitment to food, agriculture and forestry trade.

Toward a highly competitive economic area, which focuses on Competition Policy; Intellectual Property Rights; Infrastructure Development; Taxation; and Electronic commerce (e-commerce),
Toward areas with balanced economic development, which focus on Small and medium enterprise sector development.

In 2014, the Government issued Presidential Decree No. 37 of 2014 on the National Committee for the Preparation of the Implementation of the Economic Society of the Association of Southeast Asian Nations (Keppres 37/2014). This step is considered many people have entered into the time of injury time due 2015 Final MEA has been enacted whereas just 1 September 2014 Presidential Decree issued, it in fact also does not provide a policy on the Indonesian government's efforts to face ASEAN, it only gives authority to an ad agency hoc to formulate policies in dealing with MEA. Article 2 of Keppres 37/2014 authorizes the National Committee for the Preparation of MEA Implementation, namely: (i). coordinate the preparation of the MEA implementation; (ii). coordinate the acceleration of national competitiveness improvement in the implementation of the MEA; (iii). take steps to resolve obstacles and problems in the preparation and implementation of the MEA and enhancement of national competitiveness; (iv). coordinate the implementation of socialization to all stakeholders towards the preparation and implementation of the MEA as well as enhancement of national competitiveness.

After the Presidential Decree No 37 year 2014, the Government then issued the Presidential Directive No. 6 Year 2014 on the Improvement of National Competitiveness in Order to Facing the ASEAN Economic Community (Inpres 6/2014). Presidential Directive 6/2014 can be stated as the result of the MEA National Preparatory Committee established by the previous President. Inpres 6/2014 is much more concrete than the previous one, the program made directly derived from each sector to be improved its competitiveness. As follows;

National Industrial Development, which focus on priority industry development in order to comply with Asean markets; industrial development in order to secure the domestic market; $c$. development of small and medium industry; human resource development and research; implementation of Indonesian national standard (SNI);

Agricultural Development, which focuses on increased direct investment in agricultural sector and increased market access;

Development of Marine and Fisheries, which focus on institutional strengthening and position of marine and fisheries, increasing the competitiveness of marine and fisheries, strengthening the domestic market as well as strengthening and improving the export market;

Energy Development, which focus on development of power sub-sector and reduction of fossil energy use, development of new energy subsector, renewable and energy conservation and Increased energy and electricity supply to compete with countries with better infrastructure; 
Infrastructure Development, which focuses on development of infrastructure connectivity, increased competitiveness of infrastructure and infrastructure development of payment system;

\section{Development of National Logistics}

System; Banking Development;

Investment Development, which focus on a. increased investment through increased legal certainty, ease of business, expansion of investment, investment database, increased investment competitiveness, expansion of national enterprise investment in the ASEAN Region;

Development of Micro, Small and Medium Enterprises, which focus on increasing competitiveness of micro, small and medium businesses from the financing side, development of competitiveness of micro, small and medium enterprises in the framework of increasing eligibility and capability of micro, small and medium business competitiveness, as well as encouraging the empowerment of the real sector and competitiveness of micro, small and medium enterprises;

Development of Manpower Development, which focuses on increased competitiveness of workers, increased competence and labor productivity;

Health Development, which focus on increased resilience of domestic herbal medicine market, increased market access;

Trade Development, which focuses on a. stabilization and strengthening of domestic market, increased export and international cooperation, review of trade policy in supporting the implementation of Asean economic community, development of export financing facility and public education on the Asean economic community 2015

Tourism Development, which focuses on tourism destination development and tourism event development;

Entrepreneurship Development, which focuses on beginner entrepreneurs development, the role of young entrepreneurs expansion as well as business development based on new invention.

Indonesia reflects on other ASEAN countries that Small Medium Enterprises (SME) is an economic power that is able to contribute the most to domestic income and absorb the largest number of workers in almost all countries. According to a study by Bank Indonesia that the performance of MSMEs in Indonesia is still relatively low compared to ASEAN countries with relatively similar levels of development, especially in terms of productivity, export contribution, participation for global and regional production and contribution to value added $^{17}$.

The development of MSMEs in Indonesia has become one of the main priorities of Indonesian government policy, both domestically and abroad. Various programs have been done by the government in order to empower UMKM. In the country, according to data from the Ministry of Finance, there are at least five types of programs promoted by the government. The first is People's Business Credit (KUR). KUR is a credit scheme / working capital financing and / or investment specifically intended for MSMEs and cooperatives in the field of productive and feasible business. The credit / financing of KUR is less than Rp 500,000,000 under a government guarantee scheme with a maximum coverage of 80 percent of the credit limit for agriculture, marine and fisheries, forestry and small industries, and 70 percent of the credit ceiling for other sectors . The second program is Food Security and Energy Credit (KKPE). KKPE is an investment credit or working capital granted in order to support food security programs and is provided through farmer groups or cooperatives. Third, Agricultural Agribusiness Program (PUAP). PUAP is a facilitation of venture capital assistance for member farmers, both farmers, farmers, farm workers and farm households coordinated by a combination of farmer groups (Gapoktan). The next program is Business Credit Cow Breeding (KUPS). KUPS is an investment credit for cattle breeding business in the production of beef cattle or dairy cattle that obtain interest subsidy from the government. Finally, the National Program for Independent Community Empowerment (PNPM). PNPM is a community-driven development program launched by the government since 30 April 2007 and aims to alleviate poverty with communities as the designers of their own development agenda.

\section{REFERENCES}

[1] Marystella Amaldas. The Management of Globalization in Singapore: Twentieth Century Lessons for the Early Decades of the New Century, Journal of Alternative Perspectives in the Social Sciences ( 2009) Vol 1, No 3, 982-1002 Conference Report on Globalisation and Regional Security: Asian Perspective, at Hawai, http://www.apcss.org/Publications/Report_Globalization_in _Asia.html accessed october 2017.

[2] SME development in Asean. www.economica.vn/Portals/0/Documents/SME\%2520in\%2 520ASEAN\%2 520ACCA\%25202016.pdf accessed 18 September 2017.

[3] Kimura, F., Sothea, O., Fanelli, A., Richter, A., Sulaiman, S., Sovuthea, H., Sokkheang, L., Nguon, Y.A.N.A., Damuri, Y.R., Kartika, P. and Kyophilavong, P., 2014. ASEAN SME Policy Index 2014 Towards Competitive and Innovate ASEAN SMEs. Books. [4] Sato, Y., 2015. Development of small and medium enterprises in the ASEAN economies. Beyond 2015 ASEAN Strategic Action Plan for SME Development (2010 - 2015). asean.org/storage/2012/05/2-SPOA-SME2010-2015.pdf accessed September 2017 
[5]Secretariat, A.S.E.A.N., 2015. ASEAN Strategic Action Plan for SME Development, 2016-2025. ASEAN

Secretariat: Jakarta.

[6] Asean Economic Community 2015: From 10 to one. https://isca.org.sg/media/776964/isca-jun15-aseaneconomic-community-2015.pdf diakses pada 17 September 2017.

[7]AseanEconomic Community:Opportunities through Economic Integration in South East Asia. https://www.iesingapore.gov.sg/-/media/IE-

Singapore/Files/Publications/IE-

Insights/Vol22_ASEAN_Economic_Community_Opportuni ties_through_E

conomic_Integration_in_Southeast_Asia.ashx accessed 17

September 2017

[8] New Asean Economic Community could give Singapore GDP a $9.5 \%$ boost by 2030 : HSBC.

http://www.straitstimes.com/business/economy/new-aseaneconomic-community-could-give-singapore-gdp-a-95boost-by-2030-hsbc accessed 17 September 2017 [9] Budget 2017: SMEC recommends developing competitiveness, providing support for businesses. http://www.channelnewsasia.com/news/business/budget2017-smec-recommends-developing-competitivenessproviding-7537066 accessed 11 october 2017

[10] Sme committee recommendations for budget 2017 Singapore. www.sbf.org.sg/images/pdf/BR2017fullforupload.pdf accessed october 2017.

[11] Policies And Government Grants For SMEs In

Singapore, Malaysia, And Indonesia.

http://www.digitalistmag.com/future-of-

work/2017/03/16/policies-government-grants-for-smesin-singapore-malaysia-indonesia-04969798 2017

Global Talent Competitiveness Index focuses on talent and technology.

https://www.insead.edu/news/2017-global-talentcompetitiveness-index-davos accessed october 2017

[12] Malaysia, the ASEAN Economic Community, The TPP, And Intellectual Property http://www.conventuslaw.com/report/south-east-asia-iprbasics-series-malaysia-the/ accessed 20 september 2017 [13] Musa, H. and Chinniah, M., 2016. Malaysian SMEs Development: Future and Challenges on Going Green. Procedia-Social and Behavioral Sciences, 224, pp.254-262

[14]

http://www.smecorp.gov.my/index.php/en/policies/2015-

12-21-09-09-49/sme-statistics accessed october 2017

[15] SME Development Policies and Programmes. http://www.smecorp.gov.my/images/SMEAR/latest/Chapter 3.pdf Chapter 5: SME and Entrepreneurship Development Programmes in 2017

http://www.smecorp.gov.my/images/SMEAR/Chapter5.pdf accessed 1 November 2017

[16] Direktorat Jenderal Kerja Sama ASEAN, Membidik Peluang MEA, Majalah Masyarakat ASEAN Edisi 7, Maret 2015

[17]http://www.bi.go.id/id/umkm/penelitian/nasional/kajian/ Pages/Pemetaan-dan-Strategi-Peningkatan-Daya-SaingUMKM-dalam-Menghadapi-Masyarakat-EkonomiASEAN-(2015)-dan-Pasca-MEA-2025.aspx accesed 30Oktober 2017 
